\title{
CRITICS SCOFFED BUT WOMEN BOUGHT: COCO CHANEL'S COMEBACK FASHIONS REFLECT THE DESIRES OF THE 1950S AMERICAN WOMAN \\ By Christina George
}

The date was February 5, 1954. The time-12:00 P.M. ${ }^{1}$ The place-Paris, France. The event-world renowned fashion designer Gabriel "Coco" Chanel's comeback fashion show. Fashion editors, designers, and journalists from England, America and France waited anxiously to document the event. ${ }^{2}$ With such high anticipation, tickets to her show were hard to come by. Some members of the audience even sat on the floor. ${ }^{3}$ Life magazine reported, "Tickets were ripped off reserved seats, and overwhelmingly important fashion magazine editors were sent to sit on the stairs." 4 The first to walk out on the runway was a brunette model wearing "a plain navy suit with a box jacket and white blouse with a little bow tie." 5 This first design, and those that followed, disap-

\footnotetext{
${ }^{1}$ Axel Madsen, Chanel: A Woman of her Own(New York: Henry Holt and Company, 1990), 287.

${ }^{2}$ Madsen, Chanel: A Woman of her Own, 287; Edmonde Charles-Roux, Chanel: Her Life, her world-and the women behind the legend she herself created, trans. Nancy Amphoux, (New York: Alfred A. Knopf, Inc., 1975), 365.

3 “Chanel a La Page? 'But No!'” Los Angeles Times, February 6, 1954.

4 "What Chanel Storm is About: She Takes a Chance on a Comeback," Life, March 1, 1954, 49.

5 "Chanel a La Page? 'But No!”
} 
pointed onlookers. The next day, newspapers called her fashions outdated. And yet, Chanel's new designs sold well.

With negative reviews, it comes as a surprise that many American women actually liked Chanel's latest designs. When studying Chanel, historians tend to focus on her revolutionary fashion designs of the 1920s, which catered to desires for comfortable yet elegant clothing. I emphasize that it is important, if not more important, to study Chanel's lesser-known 1950s fashions as they complicate the view of American women during that period. After the second world war, Americans tried to return to a sense of normalcy. For men, this meant going back into the workforce, and for women it meant leaving the working world to become domestic housewives. They were expected to channel their increased sexual and economic emancipation into the family. ${ }^{6} \mathrm{How}-$ ever, many women returned reluctantly to these roles. To further understand this concept, we can focus solely on women's fashions. Coco Chanel caught onto this trend and chose to rebel against fashion norms by continuing to create clothing styles she knew women would want to wear rather than what they were told to wear. I argue that Chanel's fashions provided an outlet for women in the 1950s to rebel against structured ideals society set out for them. Instead, these fashions allowed them to embrace their new found liberation from previous constraints as well as reject new, more restrictive trends in 1950s fashion.

To understand why critics judged Chanel's 1950s designs so harshly, we need to have a better understanding of Chanel's innovative 1920s designs. Before and during the first world war, the look for women was less simple and highly structured. Scholar Mary Louise Roberts explains that "as the ideal of the voluptuous, curvaceous woman gave way to a sinuous smooth, 'modernist' one, the compressed structural lines and highly ornamental fashions of the previous century were radically simplified."7 Chanel distinguished the less-structured look as true fashion. Her designs were based off the idea that women did not want to wear tight fitted clothing but rather a style that blended together simple and chic. In that sense, Chanel catered to how women enjoyed dressing. Creating this "sporty" style for women shocked the world,

\footnotetext{
${ }^{6}$ Elaine Tyler May, Homeward Bound: American Families in the Cold War Era (New York: Basic Books, 2008), 105.

${ }^{7}$ Mary Louise Roberts, Civilization Without Sexes: Reconstructing Gender in Postwar France, 1917-1927 (Chicago: The University of Chicago Press, 1994), 64.
} 
especially when the look soon became the norm for women's fashion.

Chanel also embraced what became known as the "modern woman"; a concept created from the first world war. ${ }^{8}$ This new style consisted of a less structured look tied in with a more masculine clothing style. Chanel essentially created what was also known as the "poor look," giving those less wealthy the ability to dress fashionably. ${ }^{9}$ Although men were dissatisfied with this new look as they felt women should have more shape, women flocked to her designs. During the war, women chose to stick to a neutral tone of dress by not wearing such a variety of colors. ${ }^{10}$ The clothes women started to wear during the war reflected the type of work they had become involved in. ${ }^{11}$ In addition, women put away their fashion accessories and jewelry. ${ }^{12}$ This particular fashion trend remained after the end of the war. Women continued to wear this "more convenient, minimalist, pared-down look." ${ }^{13}$ Chanel was quick to catch on to women's new apparel and used it to help create her designs. According to fashion historian, Carline Rennolds Milbank, Chanel had "instinctively grasped the essence of this new epoch."14

Chanel embraced change in women's fashion by making the waistline a thing of the past and shortening the length of the skirt to well above the ankle-this became known as a "boyish look." 15 In doing so, she helped downplay the role of superiority between men and women. With a less curvaceous look, there was not any specific female body part that stood out or rather, was more important than the next. In addition, the new style of women's dress gave way to a feeling of freedom for women; it gave them a "visual fantasy of liberation." ${ }^{16}$ Chanel's fashion substantiated the idea that women actually enjoyed the clothes they wore while assuming the role of male professions during the war. Her designs not only represented a change in women's fashion but also offered reassurance that the turn of the century had brought change

${ }^{8}$ Ibid., 67.

9 “'Just a simple little dressmaker,” Life, August 19, 1957, 114.

${ }^{10}$ Roberts, 68.

${ }^{11}$ Madsen, 77.

${ }^{12}$ Roberts, 68.

${ }^{13}$ Ibid.

${ }^{14}$ Caroline Rennolds Milbank, "Chanel," in Couture: The Great Designers, (New York: Stewart Tabor \& Chang, Inc., 1985), 128.

${ }^{15}$ Roberts, 68.

${ }^{16}$ Ibid., 84. 
to the lives of women as well. ${ }^{17}$ With her "modern," "sporty," "boyish," and "emancipated" looks, Chanel had defined the New Woman. ${ }^{18}$

Unfortunately, Chanel's 1950s fashions did not satisfy critics to the same extent as her 1920s designs had. If Chanel's two big breaks onto the fashion scene both came at the end of world wars, what would make the viewers like her 1920s designs more than her comeback designs of the 1950s? We have explored the lives of women and their fashion ideals after the first world war, but now we must gain an in-depth understanding of women's lives in the 1950 s to further comprehend how Chanel's latest fashions reflected their desires. To do this, we can look at historians' work on the American culture after the Second World War. Scholar Elaine Tyler May argues that the added pressure of keeping men from becoming Communists drove women to assume the role of being quintessential domestic housewives. In the 1950s, it was more favored for women to choose marriage over a career. For those who chose both, they were viewed as being poor wives and mothers. ${ }^{19}$ Professionals concluded that men and women should return to their original family roles and counted on the woman to maintain a successful family. ${ }^{20}$ Americans put so much focus on women's roles in the family dynamic that it was hard for them not to conform to what society wanted.

May provides that with the concept that domestic ideals shaped women's identity in the 1950s, but scholar Joanne Meyerowitz, argues the complete opposite. In fact, Meyerowitz uses evidence from films, articles, and books to show how women were encouraged to become successful in the workforce after the second world war. ${ }^{21}$ In reference to postwar magazines, Meyerowitz explains that women who focused less on domesticity and more on their career were glorified. ${ }^{22}$ Some articles even "expressed ambivalence about domesticity and presented it as a problem." ${ }^{23}$ Combining the ideas of May and Meyerow-

\footnotetext{
${ }^{18}$ Claude Baillén, Chanel Solitaire, trans. Barbara Bray, (London: William Collins Sons \& Co Ltd Glasgow, 1973), 64.

${ }^{19}$ Hartmann, The Home Front and Beyond, pp. 190-193. Elaine Tyler May, Homeward Bound: American Families in the Cold War Era (New York: Basic Books, 2008), 62.

${ }^{20}$ May, 104.

${ }^{21}$ Joanne Meyerowitz, "Beyond the Feminine Mystique: A Reassessment of Postwar Mass Culture, 1946-1958," Not June Cleaver: Women and Gender in Postwar America, 1945-1960. (Philadelphia: Temple University Press, 1994), 230.

${ }^{22}$ Ibid, 251.
} 
itz, it is ever present to see that society held two separate standards for women. Women were being pulled in two different directions: one asking a woman to focus on her family and home, and the other asking her to focus on herself and career. Knowing these contradictions, it is obvious that women were most likely confused with their roles in society and within their own families.

This brings us to the criticisms and eventual praise of Chanel's 1950s fashions. Her newest designs were not given the outstanding reviews that her 1920s designs had received. But what exactly made critics so opposed to Chanel's looks of the 1950s? Before being able to understand the critic's opinions, we have to look at the fashions being introduced prior to Chanel's comeback. Between 1920 and 1940, women were the top designers in the fashion world. ${ }^{24}$ At the end of the second world war, men became the top fashion designers. Their designs returned women's clothing to the structured look that was popular before the first world war. These male fashion designers changed women's fashion by taking a "look into exaggerated, geometric shapes, bodily asymmetric and stylized directions." ${ }^{25}$ Amongst the top designers were Balenciaga, Fath, Piguet, Rochas, and the most famous of them all, Christian Dior. ${ }^{26}$ Just like the other male designers, Dior chose the complete opposite route of fashion design than the years preceding the war. With a rigid style, he dressed women in "stiffened bodices and constricted waists." ${ }^{27}$ Dior was at the forefront of these designs which soon became known as the "New Look." ${ }^{28}$ These structured designs became immensely popular, and soon after, were the silhouette that women wore. Consequently, it is these exact looks that played a large role in Chanel's comeback. She was not thrilled with these clothing designs. Chanel's goal was to not make women feel as if their dress was a disguise, but rather comfortable, flattering, and timeless. ${ }^{29}$

Chanel's competition allows an understanding as to why critics might have thought poorly of her latest designs. With her first fashion show in fifteen years, critics argued that her new designs were not for 1954-they looked

\footnotetext{
${ }^{23}$ Ibid, 232.

${ }^{24}$ Madsen, 276.

${ }^{25}$ Ibid., 277.

${ }^{26}$ Charles-Roux, 356.

${ }^{27}$ Ibid, 251.

${ }^{28}$ Baillén, 61.

${ }^{29}$ Madsen, 282.
} 
outdated. ${ }^{30}$ Some fashion writers even called her new designs "tacky" because of their sharp tailoring. ${ }^{31}$ However, in contrast, some fashion gurus gave her praise for her new designs. ${ }^{32}$ A four page spread of Chanel and her newest designs appeared in the March 1, 1954, issue of Life magazine. The magazine spread showed Chanel's designs and included a brief article about them. Unlike many before Life magazine, the writers gave her clothing good reviews. Even though these articles had a positive outlook, they still noted the repetition of style over nearly thirty years. The article stated, "Chanel has lost none of her skill. Her styles hark back to her best of the '30s-lace evening dresses that have plenty of elegant dash and easy-fitting suits that are refreshing after the 'poured-on' look of some styles."

To examine the consistency of Chanel's designs, one need only look at specific ensembles from each period. The particular 1920s design we will explore is a printed silk sleeveless dress (Fig. 1).

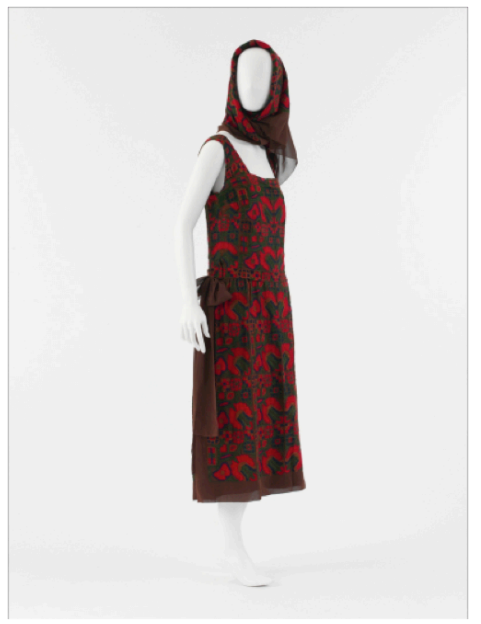

Fig. 1: A piece resembling Chanel's 1920s design style. (Photograph attributed to Gabriel Chanel (b. 1883, d. 1971), The Metropolitan Musem of Art, New York, Gift of Friends of the Costume Institute, 2005 (2005.114a, b), http://www.metmuseum. org/works_of_art/collection_database/all/ensemble_house_of_chanel/objectview_zoom.aspx?page= 5\&sort=0\&sortdir=asc\&keyword=coco chanel\&fp $=1 \& \mathrm{dd} 1=0 \& \mathrm{dd} 2=0 \& \mathrm{vw}=1 \& \mathrm{collID}=0 \& \mathrm{OID}=800$ 38147\&vT=1 [accessed June 5, 2010].)

30 “Freeneesh?”, 28; “Chanel a La Page? 'But No!’” Los Angeles Times, February 6, 1954.

31 "Freeneesh?", 28.

32 "Dior, Chanel Aim at Budget Trade," Los Angeles Times, June 18, 1957; “'Just a simple little dressmaker," Life, August 19, 1957, 113. 
With a square neckline, drop waist, and mid-calf hem, the dress is a simple, yet elegant ensemble. The fabric alone is gorgeous with a large red pattern that has interesting detail but is not overpowering. A large brown bow ties at the side of the waist adding dimension and adornment giving the dress an overall couture feel. The dress also has a matching silk headscarf that gives the outfit a sense of sophistication and completes the outfit. ${ }^{33}$

Similarly, Chanel's 1950s ensemble has the same elegance as her 1920s piece. This 1950s design (Fig. 2) is made of an off-white printed silk. It is a

Fig. 2: A piece resembling Chanel's 1950s design style. (Photograph attributed to Gabriel Chanel (b. 1883, d. 1971), Brooklyn Museum Costume Collection at The Metropolitan Musem of Art, New York, Gift of Friends of the Brooklyn Museum, 2009; Gift of H. Gregory Thomas, 1959 (2009.300.261a-c), http://www.metmuseum.org/ works_of_art/collection_database/all/ensemble_ gabrielle_coco_chanel/objectview_zoom.aspx?page $=6 \&$ sort $=0 \&$ sortdir $=$ asc $\&$ keyword $=$ coco chanel $\& \mathrm{f}$ $\mathrm{p}=6 \& \mathrm{dd} 1=0 \& \mathrm{dd} 2=0 \& \mathrm{vw}=1 \& \mathrm{coll} I \mathrm{D}=0 \& \mathrm{OID}=80$ 095321\&vT=1 [accessed June 5, 2010].)

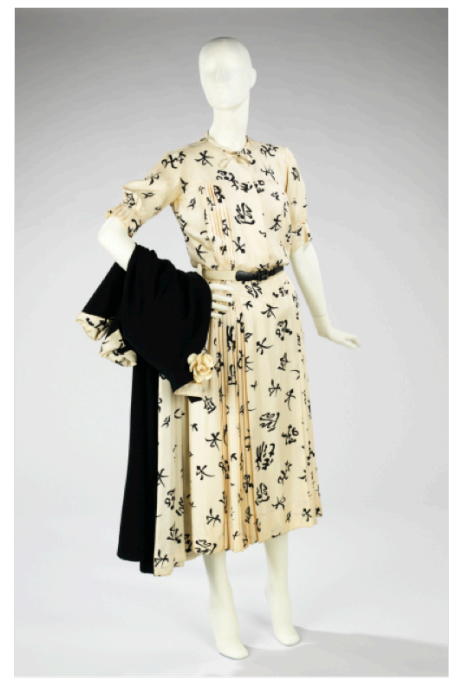

shirt waist dress with vertical pin tucking from the yoke down to below the knee hem. A simple leather belt is worn at the waist which hints at the wearer's waistline but does not make her feel confined. The sleeves of the dress are elbow length and have the same pin tucking as that of the dress. Without a

\footnotetext{
${ }^{33}$ In reference to the whole paragraph, Gabrielle "Coco" Chanel, Ensemble, 1922, The Metropolitan Museum of Art, New York, http://www.metmuseum.org/works_of_art/collection_database/all/ensemble_house_of_chanel/objectview_zoom.aspx?page=5\&sort=0\&sortdir=asc\&ke yword $=$ coco chanel $\& \mathrm{fp}=1 \& \mathrm{dd} 1=0 \& \mathrm{dd} 2=0 \& \mathrm{vw}=1 \&$ collID $=0 \& \mathrm{OID}=80038147 \& \mathrm{vT}=1$ (access ed June 5, 2010).
} 
traditional collar, the neckline has a simple string tie bow in the same gorgeous fabric as the rest of the dress. Chanel compliments this dress with a black wool coat which is lined with the same printed silk. The cuffs of the coat are turned back, revealing the lining which gives off another complete couture look. In addition, the coat is adorned with a small flower pin which gives the coat a sense of sophistication. Both pieces discussed are understated in design and reflect Chanel's signature appeal to women in each period. ${ }^{34}$

What exactly were audiences expecting to see from Chanel's designs at her comeback show? And, with such high anticipation, why were critics not pleased with her designs? As explained earlier, due to Chanel's unfading name, her 1954 fashion show drew crowds well in advance. ${ }^{35}$ It is evident that the world had hoped for something completely unique when it came to Chanel's comeback fashions. They expressed utter disbelief when the designs did not drastically change. A Los Angeles Times article, "Chanel a la Page? 'But No!" commented on the fact that Chanel's newest designs did not reflect what the world had anticipated. The author writes, "There were absolutely none of the fabulously jeweled gowns that some fashion sleuths had been busily predicting." ${ }^{36}$ What is interesting here is how many people tried to predict the new trends and never took into consideration the fact that she might actually want her fashions to look the same as they had in the past. On the contrary, they hoped that with the end of the second world war, Chanel would again bring a new style to women's fashion. When audiences did not see revolutionary designs like those she introduced in the 1920s, they considered her comeback a failure.

With so much hype about her upcoming fashion show, it seems critics forgot that Chanel would most likely abide by her original outlook on women's fashion-comfortable and chic. It seems fashion audiences around the world expected too much out of Chanel. Although spectators might have

34 "In reference to the whole paragraph, Gabrielle "Coco" Chanel, Ensemble, 1956, Brooklyn Museum Costume Collection at The Metropolitan Museum of Art, New York, http://www. metmuseum.org/works_of_art/ collection_database/all/ensemble_gabrielle_coco_chanel/objectview_zoom.aspx?page $=6 \&$ sort $=0 \&$ sortdir $=$ asc $\&$ keyword $=$ coco chanel $\& \mathrm{fp}=6 \& \mathrm{dd} 1=0 \& \mathrm{dd} 2=0 \&$ $\mathrm{vw}=1 \&$ collID=0\&OID=80095321\&vT $=1$ (accessed June 5, 2010).

${ }^{35}$ In reference to her unfading name, "French Designer Griffe Makes Most of the Tunic," Los Angeles Times, August 3, 1955; In reference to her highly anticipated designs, "What Chanel Storm is About: She Takes a Chance on a Comeback," Life, March 1, 1954, 49.

36 "Chanel a La Page? 'But No!'” 
seen Chanel's new collection as taking a step back in fashion, Chanel herself, probably saw it as continuing her legacy and keeping consistent with her ideas. Chanel stayed in the same realm of fashion while critics expected a new inventive style. Critics had set Chanel's designs on a pedestal because she transformed women's fashion in the 1920s. Critics seemed to have forgotten that Chanel never conformed to the 1920s fashion ideals. What was to say she would conform to those of the 1950s? Just as she had in the 1920s, Chanel rebelled against fashion norms in the 1950s.

The idea that Chanel's new designs would be innovative might have stemmed from the fact that she was once again introducing new designs after a world war. It was not that Chanel changed, but rather the world changed and critics thought her designs would reflect that. After the end of the second world war, people expected the same change and forgot the fact that Chanel would maintain her original views on fashion even if the world did not. With the war behind them, people might have felt as if they could finally move forward. I think seeing Chanel's fashions made critics, designers, and those wanting to purchase or replicate her fashions take a step back and question the degree to which they had actually moved forward. The world looked to Chanel's designs to reflect the progress in the postwar and used her designs to measure that. Comparing Chanel's latest fashions to her famous 1920s designs allowed critics to judge and evaluate her fashions much more closely. Incidently, her fashion comeback did not show the unstated agreement the world predicted. This could possibly be the key reason as to why so many criticized Chanel's 1950s designs. People had to question whether or not they had moved on after the second world war and made progress because her fashions were so similar to her creations of the 1920s.

Although many people throughout the world criticized Chanel's fashions, Americans took a liking to them. Despite what most thought or said about Chanel's simple designs, in the United States buyers still purchased her products. ${ }^{37}$ Scholar Pierre Galante further explains in his writings, "The American woman immediately saw what was eternally modern in the Chanel look: the breasts and hips in their places, a certain elegance, freedom of movement and the look of youth." ${ }^{38}$ Designers in the United States disregarded what the

\footnotetext{
37 "Freeneesh?" Time, February 15, 1954, 28.
}

${ }^{38}$ Galante, 210. 
press said about her fashions and immediately chose to replicate her designs by encompassing the characteristics of her styles. ${ }^{39}$ She even targeted the budget shopper by mass producing her designs in the later 1950 s. $^{40}$ Chanel understood what women wanted and geared her designs toward them. Making light of what fashion critics had to say, Chanel continued to cater to women's wants and desires. She took into consideration the idea that the modern woman was a professional who wanted comfort in her clothing. Chanel still felt women had to be practical and not be "trapped" in their clothing. ${ }^{41}$

This made her designs popular among women. The September 28, 1957, issue of The New Yorker expresses the idea that woman needed comfort and practicality. The New Yorker writes, "[Chanel's designs] present a collection of dress and suit designs that have begun to affect women's styles (and, apparently, women's minds) every bit as powerfully as her designs of thirty-odd years ago did." ${ }^{2}$ Chanel knew women wanted to work and used her clothing to demonstrate that. If women simply wore the constructed look Dior produced, they would essentially be conforming to what society and men wanted from them. Wearing Chanel's pared-down look allowed women to make a statement using their clothing. Her fashions expressed the idea that women did not want to be restricted to exaggerated feminine roles; what they wanted was to enter the work force. With Chanel's look being copied and mass produced, it was easier for women to get their hands on her designs. For instance, the two-piece suit inspired by Chanel's latest fashions was not out of the reach of an ambitious and professional woman. ${ }^{43}$ With Chanel's style of clothing more accessible, even middle class women were able to express their desire of being less influenced by what men had to say about their dress. Women could listen to their own aspirations regarding their roles in society.

As a result, American women used Chanel's 1950s designs to show men and the rest of society that they wanted to focus on themselves and their work without fully rejecting femininity and domesticity. Chanel shows she is an iconic figure in the fashion world. Her fashion designs essentially helped free

39 "H Hour, H Line," Newsweek, August 9, 1954, 52; Replicas of Chanel's designs at cheaper prices, Phyllis Lee Levin, "Spring Clothes Deserve Medals," New York Times, March 20, 1957.

40 "Dior, Chanel Aim at Budget Trade," Los Angeles Times, June 18, 1957.

41 "The Strong Ones," The New Yorker, September 28, 1957, 35.

42 Ibid, 34.

${ }^{43}$ A suite inspired by Chanel sold for about \$24.95. Galante, 211. 
women of conforming to what the male fashion designers wanted to see on them. Instead of using her voice to help change the political status of women, Chanel used her clothing designs to give women greater freedom of choice in what they wore and how they presented themselves. With her designs, Chanel influenced women to stand up for their wants and desires. Her clothing designs helped encourage American women to not only go against fashion norms but societal norms as well. 
Baillén, Claude. Chanel Solitaire. Translated by Barbara Bray. Great Britain: William Collins Sons \& Co Ltd., Glasgow, 1973.

"Chanel a la Page? 'But No!': Paris Talk Critical of Skirts Below Calf and Ill-Fitted Waists." Los Angeles Times, February 6, 1954.

“Chanel Criticizes Sack Look.” Los Angeles Times, September 9, 1957.

Chanel, Gabrielle. Ensemble. 1922. The Metropolitan Museum of Art. New York. http://www.metmuseum.org/works_of_art/collection_database/all/ensemble_ house_of_chanel/objectview_zoom.aspx?page=5\&sort=0\&sortdir=asc \&keywo $\mathrm{rd}=\mathrm{coco} \quad$ chanel $\& \mathrm{fp}=1 \& \mathrm{dd} 1=0 \& \mathrm{dd} 2=0 \& \mathrm{vw}=1 \&$ collID $=0 \& \mathrm{OID}=80038147 \&$ $\mathrm{vT}=1$ (accessed June 5, 2010).

Ensemble. 1956. Brooklyn Museum Costume Collection at The Metropolitan Museum of Art. New York. http://www.metmuseum.org/works_of_art/ collection_database/all/ensemble_gabrielle_coco_chanel/objectview_zoom.aspx ?page $=6 \&$ sort $=0$ \&sortdir $=$ asc $\&$ keyword $=$ coco chanel $\& \mathrm{fp}=6 \& \mathrm{dd} 1=0 \& \mathrm{dd} 2=0 \&$ $\mathrm{vw}=1 \&$ collID=0\&OID=80095321\&vT $=1$ (accessed June 5, 2010).

Charles-Roux, Edmonde. Chanel: Her life, her world-and the woman behind the legend she herself created. Translated by Nancy Amphoux. New York: Alfred A. Knopf, Inc., 1975.

"Dior, Chanel Aim at Budget Trade." Los Angeles Times, June 18, 1957.

"Freeneesh?” Time, February 15, 1954.

“French Designer Griffe Makes Most of the Tunic.” Los Angeles Times, August 3, 1955.

Galante, Pierre. mademoiselle Chanel. Translated by Eileen Geist and Jessie Wood. Chicago: Henry Regnery Company, 1973.

“H Hour, H Line.” Newsweek, August 9, 1954.

“Just a Simple Little Dressmaker.” Life, August 19, 1957. 
Madsen, Axel. Chanel: A Woman of Her Own. New York: Henry Holt and Company, 1990.

May, Elaine Tyler. Homeward Bound: American Families in the Cold War Era. New York: Basic Books, 2008, 93.

Meyerowitz, Joanne. "Beyond the Feminine Mystique: A Reassessment of Postwar Mass Culture, 1946-1958," In Not June Cleaver: Women and Gender in Postwar America, 1945-1960. Philadelphia: Temple University Press, 1994.

Milbank, Caroline Rennolds. "Chanel.” In Couture: The Great Designers, 120-35. New York: Stewart, Tabori \& Chang, Inc., 1985.

Nickles, Shelley. "More is Better: Mass Consumption, Gender, Class Identity in Postwar America," American Quarterly 54.4 (2002): 581-622.

Roberts, Mary Louise. Civilization Without Sexes: Reconstructing Gender in Postwar France, 1917-1927. Chicago: The University of Chicago Press, 1994.

"Serene Elegance and Taste Mark Coco Chanel Collection." Los Angeles Times, July $31,1956$.

“Spring Clothes Deserve Medals.” New York Times, March 20, 1957.

“The Strong Ones.” The New Yorker, September 28, 1957.

"What Chanel Storm is About: She Takes a Chance on A Comeback." Life, March 1, 1954. 